Плющ Руслан Миколайович доктор наук 3 державного управління, доцент, професор кафедри державного управління і місцевого самоврядування, Херсонський національний технічний університет, Бериславське шосе, 24, м. Херсон, 73008; тел.: (0552) 32-69-12, https://orcid.org/0000-0003-1135-1482

Проніна Оксана Володимирівна кандидат наук з державного управління, доцент кафедри державного управління i місцевого самоврядування, Херсонський національний технічний університет, Бериславське Шосе, 24, м. Херсон, 73008, тел.: (050) 473-59-29, https://orcid.org/0000-0002-6449-1887.

\title{
ДЕРЖАВНЕ УПРАВЛІННЯ В УКРАЇНІ В КОНТЕКСТІ НОРМ АДМІНІСТРУВАННЯ ЄС: ФУНКЦІЇ Й РОЛЬ У РОЗВИТКУ СВРОПЕЙСЬКОЇ ІНТЕГРАЦЇ̈
}

Анотація. У статті розглядаються питання проблематики визначення поняття «державне управління» та його вплив на євроінтеграцію в цілому. Європейська інтеграція є важливим стимулом для України в контексті втілення економічних реформ, примноження та зміцнення інтелектуального потенціалу українського суспільства, освоєння нових високих технологій, інноваційного розвитку економіки. Зазначено, що у вітчизняній та зарубіжній юридичній літературі немає загального визначення поняття «державне управління», що пояснюється різними підходами до вирішення цього питання. Державне управління інтерпретується з погляду сутності, реального змісту діяльності чи форм, у яких вона приймає та у яких існує. У адміністративної науці відзначається багатогранність концепції управління як виду соціального управління. Аналіз наукових праць з вивчення концепції управління дозволив виділити такі теоретико-методологические підходи до визначення цього поняття. Рекомендовано пропозиції та основні здобутки реалізації державного управління в Україні. На сучасному етапі основною вимогою до нової базової моделі системи публічного управління $\epsilon$ забезпечення дотримання принципу системності та координації вчинення тих чи інших дій та заходів, оскільки їх відсутність або нехтування призводить до проявів хаотичності, непослідовності або навіть передчасності, що порушує цілісність, стабільність та очікувану результативність функціонування системи публічного управління й адміністрування, тобто до того, що ми спостерігаємо саме сьогодні. Невирішеною проблемою залишається пошук вдалих форм організації влади в органах місцевого самоврядування 3 метою досягнення бажаного врівноваження компетенцій та повноважень, які б запобігали можливим 


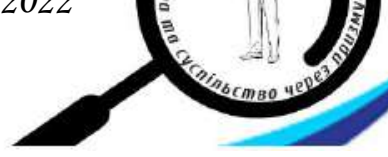

проявам сепаратизму та відповідали завданням загальнонаціо-нальних інтересів держави.

Ключові слова: державне управління, адміністрування, європейська інтеграція, демократія, виконавча влада.

Pliushch Ruslan Mykolaiovych Doctor of Science in Public Administration, Associate Professor, Professor of Public Administration and Local Self-Government Kherson National Technical University, Beryslavske Shosse, 24, Kherson, 73008, tel.: (0552) 32-69-12, https://orcid.org/0000-0003-1135-1482

Pronina Oksana Volodymyrivna Candidate of Sciences in Public Administration, Associate Professor of the Department of Public Administration and Local SelfGovernment of Kherson National Technical University, Beryslavske Shosse,24, Kherson, 73008, tel.: (050) 473-59-29, https://orcid.org/0000-0002-6449-1887.

\title{
PUBLIC ADMINISTRATION IN UKRAINE IN THE CONTEXT OF EU ADMINISTRATION STANDARDS: FUNCTIONS AND ROLE IN THE DEVELOPMENT OF EUROPEAN INTEGRATION
}

\begin{abstract}
The article considers the issues of defining the concept of "public administration" and its impact on European integration in general. European integration is an important stimulus for Ukraine in the context of implementing economic reforms, increasing and strengthening the intellectual potential of Ukrainian society, the development of new high technologies, innovative economic development. It is noted that in the domestic and foreign legal literature there is no general definition of "public administration", which is explained by different approaches to solving this issue. Public administration is interpreted in terms of the nature, real content of activities or forms in which it takes and in which it exists. In administrative science there is a multifaceted concept of management as a type of social management. Analysis of scientific papers on the study of the concept of management has identified the following theoretical and methodological approaches to defining this concept. Proposals and main achievements of public administration in Ukraine are recommended. At the present stage, the main requirement for the new basic model of public administration is to ensure compliance with the principle of systematization and coordination of certain actions and measures, as their absence or neglect leads to chaos, inconsistency or even prematurity, which violates integrity, stability and expected effectiveness. the functioning of the system of public administration and administration, that is, to what we are seeing today. The unresolved problem is the search for successful forms of government in local governments in order to achieve the desired balance of competencies and powers that would prevent possible manifestations of separatism and meet the objectives of national interests of the state.
\end{abstract}


Keywords: public administration, administration, european integration, democracy, executive power.

Постановка проблеми. Глибокі перетворення у всіх сферах суспільного життя, національне відродження України зумовили необхідність докорінного перегляду підходів до державного управління. Світові інтеграційні процеси та побудова незалежної демократичної держави потребують створення якісно нової системи управління. Державне управління - це цілеспрямований вплив, який підтримується за допомогою системи заходів та методів законодавчого, контрольного, виконавчого, характеру, що здійснюються із санкції державних органів з метою стабілізації та розвитку систем.

Світовий досвід показує, що у кожній країні організація державного управління має свої особливості.

До теоретичних проблем державного управління зверталося багато вчених і тому поняття «державне управління» достатньо широко висвітлено у ряді наукових праць. Проте слід зазначити, що у науковців до цього часу немає одностайності у тлумаченні терміна «державне управління».

Термін «державне управління» широко використовувався в законодавстві радянського періоду й ототожнювався 3 виконавчо- розпорядчою діяльністю. Конституція України [1], прийнята 28 червня 1996 року, відмовилася від прямого використання терміна «державне управління» і застосувала термін «виконавча влада». Пояснюється це конституційним проголошенням принципу поділу державної влади на виконавчу, законодавчу та судову (ст. 6 Конституції України). Це призвело до деяких труднощів, наразі в Україні немає визначення державного управління на законодавчому рівні. Державне управління - це реальність, без якої не може функціонувати механізм державної влади. У свою чергу, прогалини як у теорії, так і в законодавстві викликають різні дискусії щодо визначення цієї категорії та значні труднощі у розкритті їі структури, елементів механізму та їх юридичного закріплення.

Аналіз останніх досліджень і публікацій. Вагомий внесок у розвиток теоретичних основ щодо визначення ознак та правової природи поняття «державне управління» внесли такі вчені, як: В.Б. Авер'янов, О.Ф. Андрійко, Ю.П. Битяк, І.П. Голосніченко, В.Я. Малиновський, Н.Р. Нижник, О.Ф. Скакун, О.І. Ющик; російські дослідники: Г.В. Атаманчук, І.Л. Бачило, Ю.М. Козлов, Б.М. Лазарєв, Г.Х. Попов, Ю. М. Старілов, Ю.О. Тихомиров, В.Є. Чіркін та ін. Питанням державного управління було присвячено дисертаційні дослідження А.М. Волощука, І.С. Зав’ялової, Д.М. Павлова, Н.С. Панової та ін. У результаті різних монографіях і навчальних публікаціях можна знайти безліч визначень поняття державного управління.

Мета статті $\epsilon$ аналіз основних принципів функціонування державного управління в країнах ЄС та можливості їх застосування для України. 


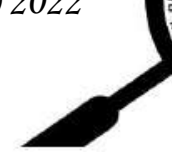

Виклад основного матеріалу. При вивченні концепції державного управління значна кількість вчених пов'язує управлінську діяльність із процесом функціонування виконавчої влади, внаслідок чого фактично ототожнюється державне управління 3 управлінською діяльністю виконавчих органів. Приклади такого трактування державного управління можна знайти у роботах О.П. Альохіна, А.О. Кармолицького, Ю.М. Козлова, А.П. Коренєва, Д.М. Овсянко, Ю.С. Шемшученка та інші. Така позиція вчених знаходить відображення у захисті того фундаментального факту, що «державне управління та його державні органи є частиною єдиного механізму державної влади» і що замість терміна «державне управління» використовується інший термін - «виконавча влада», а виконавчі органи по суті є органами державного управління.

Також слід зазначити вплив радянської юридичної науки. Концепції державного управління та виконавчої діяльності використовувалися багатьма радянськими вченими майже ідентичні. Це пов'язано 3 тим, що за часів Радянського Союзу концентрація всіх повноважень з управління суспільством та державою була в єдиному центрі влади, в основі якої лежала система органів виконавчої влади, яка на законодавчому рівні називалися публічною владою.

Щодо сучасних наукових досліджень, на підтримку цього підходу висловлюються такі думки. Ю.М. Козлов пропонує таке визначення: «державне управління - це виконавча діяльність держави, що здійснюється органами державного управління або виконавчим апаратом. «При цьому основною метою державного управління, на його думку, $\epsilon$ виконання (реалізація) вимог ухвалених законів». Державне управління - управління у широкому значенні та форма практична реалізація виконавчої влади у власному розумінні» [2,c.10]. Д.М. Овсянко вважає, що центральним поняттям науково-правового аналізу має бути поняття «виконавча влада», а не «державне управління» як державне управління. не більше ніж безпосередня діяльність органів виконавчої влади в економічній (економічній), соціокультурній та адміністративно-політичній сфері [3,c.124]. Н.Р. Нижнік та О.А. Машков, характеризуючи державне управління, зазначають, що даний «підзаконний акт виконавчої влади», спрямований на практичну організацію нормального життя та забезпечення особистої безпеки громадян, створення умов для їхнього матеріального, культурного та духовного розвитку» [4,c.6]. В.В. Цвєтков стверджує, що громадське управління - це форма практичного здійснення виконавчої влади [5, с.18].

Прикладом визначення «державного управління» у західній літературі через поняття «виконавча влада» $\epsilon$ визначення, дане у всесвітньо відомій енциклопедії «Британіка»: «Державне управління - це діяльність, що включає реалізацію політики та програм уряду (Виконавча влада). Сучасне державне управління включає діяльність 3 визначення державної політики, але 
переважно займається плануванням, організацією, керівництвом, координацією та контролем дій уряду» [6].

Щойно згаданий підхід до тлумачення поняття «державне управління» $\epsilon$ основою «вузького» чи «особливого» підходу на відміну так званого «широкого» підходи до визначення державного управління. Між цими двома підходами до визначення державного управління ведеться основна дискусія у науковому співтоваристві. Загалом співвідношення цих підходів має такий вигляд. У вузькому значенні категорія державного управління відбиває щодо самостійного виду державної діяльності, яку здійснює певна частина органів державної влади. У широкому значенні державне управління окреслюється сукупністю всіх видів діяльності держави, тобто всіх форм державної влади загалом.

Серед західних учених Д. Вілсон, Д. Грінвуд, Р. Грегорі, У. Джон, Л. Нігро, Ф. Нігро, М. Роскін та інші пропонують «широкий» підхід до розуміння державного управління. Вони вважають, що державне управління пов'язане 3 трьома сферами влади - законодавчою, виконавчою та судовою. Найбільш послідовно цю точку зору висловлюють американські вчені Ф. Нігро та Л.А.Нігро, які дають таке визначення: «Державне управління означає скоординовані групові дії у громадських справах:

1) що належать до трьох сфер влади - законодавчої, виконавчої, судової та їх взаємодії;

2) які важливі для формування державної політики та $є$ частиною політичного процесу;

3) суттєво відрізняється від менеджменту у приватному секторі;

4) тісно пов'язані 3 численними приватними групами та окремими особами, які працюють у різних компаніях та спільнотах» [7, с.10].

Розробка політики $€ C$ у сфері державного управління $\epsilon$ проміжним продуктом розробки та реалізації спільних політик у різних секторах та юридичних вимог до адміністративних структур та процедур у державахчленах. Однак відсутність повноважень у сфері державного управління не заважає Свропейському Союзу формулювати заходи, які прямо чи опосередковано впливають на цю політику в державах-членах.

Незважаючи на відсутність правових підстав для запровадження правових норм, наявність загального консенсусу 3 цього питання призвела до запровадження спільних для держав-членів ЄС принципів державного управління, незважаючи на їх різні правові та організаційні традиції.

3 роками ці принципи були визначені та уточнені у судовій практиці національних судів, а потім у судовій практиці Суду Європейського Союзу. У державах-членах СС ці стандарти разом із принципами, закріпленими в конституційних положеннях, зазвичай вбудовані або представлені у формі низки нормативних актів, таких як адміністративні процесуальні кодекси, адміністративні процесуальні кодекси, закони про свободу інформації, закони про державну службу. Законодавство та політика ЄС значно впливає на 
розвиток адміністративного права та адміністративних структур у державахчленах СС. Більшість сфер державного управління регулюються законодавством СС або перебувають під його впливом. Ініціативи, які стосуються окремих адміністрацій державного управління, одночасно охоплюють певну концепцію з чітко визначеними цілями та стандартами в галузі управління. Це чітко простежується у процесах лібералізації раніше монополістичних секторів економіки, таких як зв'язок, транспорт та енергетика через прийняття та застосування відповідного закону про конкуренцію.

Саме в цих сферах законодавство $С$ С потребує ринкових адміністративних реформ у державах-членах. Розвиток прав людини та громадянина, який нещодавно був зосереджений на Хартії основних прав $\mathrm{CC}$, також важливий для формулювання політики державного управління. Статті 41 та 42 Хартії основних прав гарантують право на гарне адміністрування та доступ до урядових документів.

Пряма та активна участь України у сучасних інтеграційних процесах об'єктивно обумовлена перевагами міжнародного поділу праці, а також необхідністю подолання штучного відділення України від світової економіки за рахунок одностороннього розвитку в рамках СРСР та РЕВ.

Сьогодні в Україні існує стратегія зовнішньоекономічної діяльності, спрямована на розвиток торгівлі в Україні, участь України у міжнародному поділі праці, а також обмін знаннями, досвідом та технологіями. Тому 3 початком самостійного існування Україна взяла курс на активну участь у євроінтеграційних процесах.

Але для того, щоб інтеграція в Україні була ефективною, нашій державі потрібні певні політичні, правові, соціокультурні, економічні та інфраструктурні передумови.

Серед основних політичних та правових передумов інтеграції України такі: політичне визначення України, забезпечення територіальної цілісності та створення адекватної системи національної безпеки, безумовне виконання міжнародних зобов'язань, особливо у галузі прав людини, запровадження прийнятного громадянства, перегляд існуючих політичних практик. відносини 3 державами колишнього СРСР, безпосередня участь у регіональних та глобальних політичних процесах, формування відповідного законодавства та розробка ефективних механізмів та інструментів його реалізації.

У цьому контексті особливо важливими є економічні передумови для інтеграції. Вони формуються на основі економічної та інституційної підтримки суверенітету, оцінки економічного потенціалу та напрямів структурної перебудови, розробки та реалізації продуманої програми переходу до ринкових відносин з пріоритетом приватизації та приватизації, соціального захисту, оцінки експортного потенціалу, розробка експортно-імпортної стратегії та адекватного механізму зовнішньоекономічна діяльність та багато інших економічних аспектів. 
Сьогодні ефективна інтеграція України у світовий економічний простір $є$ актуальним завданням побудови державності та економіки, але для того, щоб цей процес справді приніс очікувані результати, необхідно розуміти деякі особливості інтеграції України.

Говорячи про інтеграційний досвід України, насамперед слід відзначити європейський вибір України, який був зумовлений усвідомленням можливості інтеграції як чинника створення державної незалежності, безпеки, політичної стабільності та багатьох інших елементів політичного, економічного та соціального благополуччя.

Інтерес до орієнтації України на членство в СС можна пояснити тим, що прихильники цієї зовнішньої політики поширили думку, що вступ України до Європейського Союзу дозволить підвищити політичний авторитет країни на міжнародній арені та бути в центрі уваги світової політики.

На законодавчому рівні позицію України щодо $\mathrm{CC}$ вперше було сформульовано в «Основних напрямах зовнішньої політики України», затверджених Постановою Верховної Ради України 2 липня 1993 року. Цікаво, що на момент розробки документа: Україна всерйоз не розглядала можливість інтеграції до $\mathrm{CC}$, що підтверджує позицію документа про те, що «членство в Європейських спільнотах є не пріоритетом, а перспективною метою української зовнішньої політики». часто пов'язують із тим, що ще до розпаду Радянського Союзу Україна була одним із засновників Співдружності Незалежних Держав. Саме цей факт відштовхував, а, можливо, навіть стривожені, багато європейців та Європи більше не хотіли повзати з Україною, яка ще не повністю відмовилася від свого радянського минулого, тим більше що на той час передбачалося, що СНД може стати політичним наступником Радянського Союзу.

При цьому в Європі було вирішено укладати угоди на двох рівнях. Так було укладено Угоди про асоціацію з Свропою з країнами Центральної та Східної Свропи, а країнам СНД було запропоновано укласти Угоди про партнерство та співробітництво, які встановлювали межі відносин між Європою та Європою на найближчі 10 років 3 можливістю подальшого продовження.

Сьогодні модернізація держави та державного управління - неминучий виклик сучасності, про що свідчить іiі реалізація в країнах, які дійсно зацікавлені у правильному функціонуванні державного апарату та його відповідності, насамперед, реальним потребам суспільства.

Узагальнюючи досвід перетворень державного управління більшості країн, можна назвати, що вони відбувалися двома шляхами:

1) у низці країн ці реформи стартували як частину загальної соціальноекономічної політики, спрямованої на обмеження державного регулювання економіки (Великобританія, Нова Зеландія, Австралія);

2) в інших країнах реформа держсектора відбувалася у відповідь на кризу в економіці (США, Канада, Німеччина). 
При цьому різноманітність форм державного управління навіть серед країн, що вже входять до Свропейського Союзу, різна швидкість запровадження таких популярних принципів управління державним управлінням, як ефективність та результативність, а також труднощі впровадження нових методів державного управління сприяли неоднорідному розумінню. і, відповідно, неоднорідність процесу реформ. Основна проблема сучасного етапу реформи державного управління - це концептуальний вибір моделі та побудова адекватного механізму управління реформою.

Немає сумнівів у тому, що різноманітність моделей державного управління у різних країнах багато в чому зумовлена політичними, економічними та культурними наслідками. Серед найважливіших факторів, що визначають тип моделі державного управління - ринкова економіка, децентралізація влади, регіональна політика у сфері якості життя та реалізація соціальних проектів щодо забезпечення рівності та справедливості, розвиток громадянського суспільства.

Детальний аналіз досвіду розвинених країн щодо проведення адміністративної реформи дозволяе виявити схожі складові реформ, що дозволяє говорити про транснаціоналізацію адміністративної реформи. Багато в чому це пов'язано з тим, що приблизно однаковий рівень соціальноекономічного розвитку, політична організація європейських держав викликала деякі загальні тенденції у вирішенні адміністративних та державних проблем.

Сучасні тенденції у системі державного управління грунтуються на певному етапі інноваційного розвитку суспільства та допомагають формувати завдання для нової політики державного управління.

Наслідком запровадження нововведень державного управління та розвитку демократичних принципів громадянського суспільства у напрямі відповідності європейським цінностям стало оновлення системи державного управління та адміністрування. Виникла гостра необхідність у визначенні стратегічного курсу його розвитку та пов'язаних із ним завдань, які лягли в основу нової політики державного управління.

Розвитку нових поглядів на державне управління та управління сприяли також тенденції, що виявились у новій політиці державного управління, яка виявилася у просуванні адміністративно-територіальних реформ та розвитку органів місцевого самоврядування у плані розширення їх діяльності. повноваження. Звісно, це була відповідь на вимоги часу. Створено велику кількість об'єднаних територіальних спільнот; Згодом органи місцевого самоврядування отримали не лише деякі повноваження та функції, а й значні фінансові ресурси для вирішення життєво важливих для регіонів питань, насамперед пов'язаних із освітою та здоров'ям.

Державна політика України останнім часом зазнала суттєвих змін щодо гармонізації національного законодавства $з$ європейським, відбулася подальша модернізація існуючої системи державного управління та місцеве 
самоврядування. Останнім часом сфера державного управління була підпорядкована управлінській парадигмі, що підтверджується орієнтацією на користувача, ефективністю управлінської діяльності та тенденцією сприймати держслужбовців як ефективних менеджерів. Тобто управління громадською сферою переймає підходи та методи, властиві менеджменту.

Вчені зазначають, що у більшості розвинених країн використовуються методи недержавного сектора, методи, спрямовані на передачу певних повноважень 3 найвищого рівня на місцевий, просуваючи при цьому процеси взаємодії та взаємодії з органами місцевого самоврядування. Проблемною областю системи державного управління $є$ розробка адекватної моделі адміністративно-територіальної організації влади, яка буде тісно пов'язана 3 новими функціями та компетенціями органів місцевого самоврядування, які підпорядковуватимуться єдиним територіальним громадам (далі - ТГ). громадянське суспільство. Саме у зв'язку з цим вчені вказують на створення ТГ відповідно до положень Європейської Хартії місцевого самоврядування. У зв'язку з цим необхідно звернути увагу на пошук необхідного балансу у застосуванні переваг як централізованого, так і децентралізованого управління, оскільки розмежування їх взаємних недоліків сприятиме надійності та ефективності механізму державного управління, тобто побудові досконалої моделі уряду, стабільний соціально-економічний та культурний розвиток територій.

Заходи щодо реалізації стратегії реформування державного управління України на 2022-2025 роки здійснюватимуться за рахунок коштів державного бюджету та інших джерел, зокрема за рахунок проектів міжнародної технічної допомоги. Орієнтовні обсяги фінансування, необхідні для реалізації заходів цієї Стратегї, будуть уточнені при формуванні відповідних бюджетних програм, в рамках яких ці заходи будуть реалізовані, або 3 урахуванням фактично одержаної міжнародної технічної допомоги.

Міністр Кабінету Міністрів України є політичним лідером реформи державного управління та відповідає за іiі реалізацію, моніторинг та оцінку реалізації цієї Стратегії та підготовку звітів про реформу державного управління. Подальший розвиток державного управління вимагає не лише відповідного законодавства, а й досконалої інституційної основи, трансформації командно-адміністративної вертикалі влади відповідно до демократичних моделей правління. Адже важливо не лише ухвалити закони про якість, а й їхнє ефективне виконання, яке передбачає достатнє інституційний потенціал для цього.

При вдосконаленні державного управління заслуговує на увагу сучасний досвід країн Євросоюзу. Таким чином, європейська система державного управління надає більше можливостей для адаптації та використання інновацій, що сприяє динаміці державного управління та сучасному ефективному впливу, запобігаючи таким чином застарілим методам 
державного управління. Свропейський Союз досягнув розвитку завдяки цьому принципу організації механізмів державного управління.

Україна має зосередитись на зміцненні довіри між державою та населенням країни. Саме на цей аспект український уряд має звернути увагу, якщо він хоче й надалі розвиватися у напрямі європейської інтеграції. Без досягнення довіри та взаєморозуміння між державою, населенням чи громадянами України ми ніколи не зможемо побудувати європейську державу, боротися 3 корупцією та забезпечити сталий розвиток держави, яка буде глобально конкурентоспроможною.

Завдання створення нової моделі вітчизняного публічного управління очевидне, оскільки існуюча не відповідає сучасним викликам та тенденціям розвитку. У вітчизняній практиці використовувалися деякі елементи апробованих у світі моделей, що дозволило зробити висновок необхідність поєднання елементів моделей належного управління, нового державного управління, багаторівневого управління і так далі. Тобто участь суспільства та його організацій у розробці та реалізації рішень державного управління очевидна. Нині основними формами такої участі є громадське обговорення політичних та управлінських рішень, моніторинг політики та громадський контроль. Проте їх використання неефективне через неузгодженість інтересів різних соціальних груп.

Реалізація системних змін розпочалася лише у 2014 році, коли Кабінет Міністрів України ухвалив Концепцію реформування місцевого самоврядування та територіальної організації влади. Однак, згідно з першими результатами, незважаючи на позитивний ефект від передачі повноважень на місцях для вирішення проблем регіонального розвитку та підвищення ефективності управління, зростання витрат місцевого самоврядування не підтримується відповідним збільшенням фінансових ресурсів, достатніх для їхнього покриття.

Вивчення досвіду децентралізації державного управління у європейських країнах показує, 3 одного боку, явну тенденцію до посилення ролі територіального самоврядування у суспільстві, 3 другого - послідовний i рішучий курс забезпечення фінансового самоврядування. достатність територіальних громад. У результаті покращилася як якість життя громадян, так i загальне відновлення державних фінансів. Тому 3 огляду на незавершеність реформи децентралізації в Україні доцільно вивчити закордонний досвід децентралізації державного управління, щоб застосувати його на практиці в Україні.

Висновки. Проаналізовано Україну в процесах європейської інтеграції та зазначено, що співробітництво в рамках двох найбільших європейських інтеграційних об’єднань надало Україні багато переваг і досвіду участі в подібного роду різноманітних самітах та конференціях. Хоча на даний момент співпраця в рамках обох цих об’єднань трохи призупинилося. Робота з СНД 
перетворилася на таку собі співпрацю в торгівельній сфері, що не відповідає сучасним поглядам на інтеграцію. Хоча в рамках співпраці з СС все ще залишається декілька перспективних проектів, які демонструють, що ЄС все ще зацікавлено в сильній та потужній Україні в якості свого сусіда. Зважаючи на те, що Україна набула статусу безпосереднього сусіда розширеного Свропейського Союзу, особливо важливого значення набуває оновлення стратегії розвитку транскордонного співробітництва, заснованої на європейських принципах. Так останнім часом особливої уваги приділяється так званому транскордонному співробітництву Україна - СС.

Також можна сказати, що Україна як суверенна держава поки що не має такого значного впливу на інтеграційні процеси в Свропі, як хотілося б, але основи для руху в правильному напрямку вже закладені. Наприклад, вважається, що ядром створеної у рамках СНД організації ГУАМ є Україна.

Перебуваючи в центрі Європи, поряд із країнами, які активно реструктурують свою економіку, Україна помітно відстає та не встигає за процесами, що відбуваються у сусідніх країнах.

\section{Лimepamypa:}

1. Конституція України: прийнята на п’ятій сесії Верховної Ради України 28 червня 1996 року // Відомості Верховної Ради України. - 1996. -№ 30. - Ст. 141.

2. Алехин А.П. Административное право Российской Федерации: учеб. / Алехин А.П., Кармолицкий А.А., Козлов Ю.М. - М. : ИКД«Зерцало-М», 2003. - 608 с.

3. Овсянко Д.М. Административное право / Д.М. Овсянко. - М. : Юрист, 1995. - 304 с.

4. Нижник Н.Р. Системний підхід в організації державного управління : навч. посіб. / Н.Р. Нижник, О.А. Машков. - К. : Вид-во УАДУ, 1998. - 159 с.

5. Реформування державного управління в Україні: проблеми і перспективи : монографія / Кол. авт.: В.В. Цвєтков (наук. кер.) [С.Д. Дубенко, Н.Р. Нижник та ін.] - К. : Оріяни, 1998. - 364 с.

6. The New Encyclopedia Britanica, vol. 9. - Founded 1768, 15-th edition. Inc., Chicago, 1993. - P. 777.

7. Райт Г. Державне управління / Глен Райт; пер. з англ. С. Івашка, О. Коваленка, С. Соколик. - К. : Основи, 1994. - 191 с.

8. Лопушинський І.П. Актуальні проблеми реформування державної служби в Україні на новому етапі державотворення / І.П. Лопушинський II Наукові праці [Чорноморського держ. ун-ту ім. П. Могили комплексу «Києво-Могилянська академія»]. Сер. : Державне управління. - 2010.-Т. 147.-Вип. 135.-С. 6-11.

\section{References:}

1. Konstitucija Ukraïni: prijnjata na p'jatij sesiï Verhovnoï Radi Ukraïni 28 chervnja 1996 roku [The Constitution of Ukraine: adopted at the fifth session of the Verkhovna Rada of Ukraine on June 28, 1996].Vidomosti Verhovnoï Radi Ukraïni-Bulletin of the Verkhovna Rada of Ukraine [in Ukrainian].

2. Alehin, A.P. (2003). Administrativnoe pravo Rossijskoj Federacii [Administrative law of the Russian Federation]. M. : IKD «Zercalo-M» [in Russian].

3. Ovsjanko, D.M. (1995). Administrativnoe pravo [Administrative law]. M. : Jurist [in Russian].

4. Nizhnik N.R. (1998). Sistemnij pidhid v organizaciï derzhavnogo upravlinnja [System approach in the organization of public administration]. K. : Vid-vo UADU [in Ukrainian]. 
5. Cvetkov, V.V. (1998). Reformuvannja derzhavnogo upravlinnja v Ukraïni: problemi $i$ perspektivi [Reforming public administration in Ukraine: problems and prospects]. K. : Orijani [in Ukrainian].

6. The New Encyclopedia Britanica, vol. 9. - Founded 1768, 15-th edition. Inc., Chicago, 1993. - P. 777.

7. Rajt, G. (1994). Derzhavne upravlinnja [Public Administration]. K. : Osnovi, 1994 [in Ukrainian].

8. Lopushins'kij, I.P. (2010). Aktual'ni problemi reformuvannja derzhavnoï sluzhbi v Ukraïni na novomu etapi derzhavotvorennja [Actual problems of civil service reform in Ukraine at the new stage of state formation]. Naukovi praci Chornomors'kogo derzh. un-tu im. P. Mogili kompleksu "Kicvo-Mogiljans'ka akademija» Ser.: Derzhavne upravlinnja-Scientific works of the Black Sea state. University named after P. Graves of the Kyiv-Mohyla Academy complex. Ser. : Governance, 147, 135, 6-11 [in Ukrainian]. 